DOI: https://doi.org/10.32839/2304-5809/2021-3-91-67

УДК 658.62:[343.148+347.948](477)

Тищенко Г.В., Кравченко Р.В.

Харківський науково-дослідний експертно-криміналістичний центр

Міністерства внутрішніх справ України

\title{
ТЕОРЕТИЧНІ ТА ПРАКТИЧНІ АСПЕКТИ ПРОВЕДЕННЯ ТОВАРОЗНАВЧОЇ ЕКСПЕРТИЗИ КОНТРАФАКТНОЇ ПРОДУКЦІЇ
}

\begin{abstract}
Анотація. У статті вивчено проблему теоретичних та практичних аспектів проведення товарознавчої експертизи контрафрактної продукції як ключової частини комплексного дослідження товарів для виявлення ознак їі контрафрактності. З’ясовано основні відмінності понять «контрафакт» та «фальсифікат», встановлено зв'язок між цими двома поняттями. З'ясовано потенційні наслідки контрафакції товару. Вивчено базові способи контрафакції продукції. Визначено основні ознаки контрафактності товарів. Досліджено основні види контрафакції. Вивчено структуру експертизи контрафрактної продукції та їі окремі етапи. Вивчено специфріку застосування ідентифікації як основного засобу проведення експертизи. З'ясовано основні характеристики товару, які досліджують під час експертизи. Виявлено необхідність застосування комплексу експертиз для виявлення ознак контрафактності товару.
\end{abstract}

Ключові слова: контрафракт, фальсифікація, товарознавча експертиза, експертиза, підробка, ідентифрікація.

Tyshchenko Hanna, Kravchenko Roman Kharkiv Scientific Research Forensic Center of the Ministry of Internal Affairs of Ukraine

\section{THEORETICAL AND PRACTICAL ASPECTS OF CONDUCTING COMMODITY EXPERTISE OF COUNTERFEIT PRODUCTS}

Summary. The article examines the problem of theoretical and practical aspects of conducting commodity expertise of counterfeit products as a key part of a comprehensive study of goods to identify signs of their counterfeiting. The main differences between the concepts of "counterfeit" and "counterfeit" are clarified, and the connection between these two concepts is established. The possibility of detecting signs of counterfeit goods in the process of other types of commodity expertise and other types of expertise in the process of complex research is investigated. The potential consequences of counterfeit goods for the state, copyright holders and end users are clarified. The basic methods of product counterfeiting are studied and the prospects for increasing this list are evaluated. The main signs of counterfeit goods are identified. An assessment of the need for the availability of original goods for comparative analysis in the process of commodity expertise is given. The limits of the expert's authority in drawing up conclusions are studied. The main types of counterfeiting are studied, including: assortment, qualitative, quantitative, cost and informational. The necessity of studying the object for compliance with the state standards of Ukraine as part of the expert examination is revealed. The structure of expertise of counterfeit products and its individual stages are studied. The list of original samples that can be submitted for examination for comparison has been clarified. The features of conducting research in the absence of the original product are determined. The specifics of using identification as the main means of conducting an expert examination are studied. The main characteristics of the product that are examined during the examination are clarified. The necessity of studying product information as a separate stage of conducting an expert examination is investigated. It indicates basic manipulations with this data that may become grounds for recognizing the product as counterfeit, namely: incompleteness, distortion and unreliability of information. The necessity of using a complex of examinations to identify signs of counterfeit goods is revealed.

Keywords: counterfeit, falsification, commodity expertise, expertise, forgery, identification.

Постановка проблеми. Розвиток глобального ринку призводить до збільшення кількості товарів, їх груп та різновидів. З’являються нові торгові марки та, відповідно, юридичні й фрізичні особи, які намагаються їх підробити. Різна купівельна спроможність населення різних держав зумовлюе появу контрафрактної продукції та її поширення. Вдосконалення технології підробки товарних знаків, складність виявлення незаконного запозичення інтелектуальної власності та технологій виробництва товарів, поширення інформаційної продукції без дозволу правовласників зумовлюе й ускладнення виявлення контрафакції у процесі дослідження готових виробів. Необхідністю дослідження теоретичних та практичних аспектів проведення товарознавчої експертизи контрафактної продукції зумовлено написання цієї статті.
Аналіз останніх досліджень і публікацій. Темою теоретичних та практичних аспектів проведення товарознавчої експертизи контрафрактної продукції цікавились вітчизняні та іноземні науковщі, серед яких: В. Коварда, С. Л. Панов, О. Штефран та інші. В. Чеботарьов вивчав види та специфіку порушень авторського та суміжного права, В. Пирогова аналізувала теоретичні та практичні аспекти інформаційної контрафракції, а Н. Л. Арістова досліджувала основні ознаки контрадрактної продукщії.

Виділення не вирішених раніше частин загальної проблеми. Попри попередні дослідження актуальним залишається вивчення теоретичного та практичного вимірів товарознавчої експертизи контрафрактної продукцї з урахуванням їі особливостей. Необхідно також визначити взаємозалежність товарознавчої та інших видів експер- 
тизи під час комплексного дослідження продукції для виявлення в неї ознак контрафрактності.

Мета статті полягає у вивченні теоретичних та практичних аспектів проведення товарознавчої експертизи контрафрактної продукції.

Виклад основного матеріалу. Перш за все варто виявити проблему визначення поняття «контрафракт», досить часто його ототожнюють 3 поняттям «фральсиорікат», що створюе певні труднощі під час проведення дослідження та розгляду його результатів. Контрафракція - це протиправне використання певними юридичними та фізичними особами відомих товарних знаків, які їм не належать, з метою отримання збагачення. Контрафакт, як правило, схожий на товари згаданих вище форм, проте має деякі відмінності або є аналогічним, проте виготовленим 3 порушенням авторських прав чи використанням чужого патенту. Фальсифрікат є ширшим поняттям, яке охоплює увесь спектр підробок об'ектів купівлі чи продажу з метою збагачення. Найчастіше фральсифрікат зберігає найвиразніші ознаки оригінального товару, при цьому інші якісні чи кількісні показники $є$ набагато нижчими. Контрафракція $є$ одним 3 видів фральсифікації, проте є суміжною з іншими видами через необхідність дослідження відповідності ознак товару фрізикохімічним вимогам.

Контрафракція товару має ряд негативних наслідків, які можна розділити умовно на чотири групи: збитки для держави через зменшення обсягу податків, які надходять до бюджету та державних фрондів; збиток іміджу країни шляхом зниження інвестиційної привабливості; збиток правовласникам торгових марок, знаків, авторських прав, патентів, тощо; заподіяння шкоди здоров'ю споживачам підробленої продукції [4, с. 257-259]. Найпоширенішими видами контрафракції продукції $є$ :

- виготовлення та/або реалізація товарів з використанням маркувань аналогічних чи подібних до ступеня змішування 3 торговими марками інших виробників;

- виготовлення товарів, зовнішньо тотожних чи схожих на товари інших виробників з порушенням права на промисловий зразок;

- протиправне виробництво та використання інтелектуальної власності (часто для позначення цього виду контрафракції застосовують термін «піратство»), до якої належать: твори мистецтва, літератури, науки, комп'ютерні програми та аудіовізуальна продукція;

- виготовлення продукції з незаконним використанням технології, яка має статус винаходу чи корисної моделі.

Водночас постійно виникають нові види підробки продукщії. Це вимагає систематичного та послідовного вдосконалення засобів виявлення ознак контрафрактності товарів на ринку [2, с. 305-307; 3, c. 13-15].

Визначення контрафрактної продукщії під час товарознавчої чи комплексної експертизи передбачає порівняння вилучених зразків та оригінальної продукщії. Для цього експерт повинен визначити: подібність маркувань та товарних знаків, нанесених на зразок та оригінальну продукцію; відповідність маркування зразків оригінальним товарам; можливість ідентифрі- кації товарних знаків на вилученій продукщії 3 оригінальною; тотожність чи подібність ознак вилучених зразків та оригінальних товарів; відповідність паковання товарів 3 урахуванням оформлення та технології виготовлення; відповідність виробу вимогам Державного стандарту України; склад зразків (матеріали, речовини) та можливу шкоду, яку вони можуть нанести здоров’ю та життю людини [5, с. 74-75].

Залежно від виду товару, його належності до групи товарів за державними класифікаторами та особливостей виготовлення і складу список завдань може змінюватись. При цьому експерт не визначає чи є товар контрафактним, його завданням є з'ясування відповідності ознак вилучених зразків та оригіналу продукції. Усі інші дії, пов'язані з доведенням легальності виготовлення, реалізації, тощо не є складовою експертизи.

Виявлення контрафрактності товару може відбутись під час дослідження вилучених зразків 3 метою визначення фральсифікації. Таким чином контрафакція може бути:

- асортиментною;

- якісною (підробка продукцї шляхом додавання харчових та нехарчових домішок з метою поліпшення органолептичних характеристик товару зі збереженням чи втратою частини інших ознак);

- кількісною (значні відхилення у розмірі, вазі чи об'ємі товару);

- вартісною (виготовлення та/або продаж товарів нижчої якості за ціною високоякісного, цей вид супроводжує й інші види фральсифрікаціі);

- інфрормаційною (надання неточної, неповної чи спотвореної інфрормації про товар).

Що стосується організації та проведення дослідження, то першочерговою умовою є наявність оригінального зразка, який експерт застосовує для порівняння зі спірним вилученим об'єктом. Серед них вирізняють порівняльні, стандартні та еталонні зразки, які мають заздалегідь відомі характеристики (справжність, місце виготовлення, фрізико-хімічні ознаки та інше). За його відсутності експерт визначає список показників, за якими визначають: приналежність об’екта дослідження до тієї чи іншої групи товарів відповідно до державних класифікаторів; його відповідність науково обгрунтованим показникам достовірності.

Основною метою дослідження є визначення відповідності об'єкта дослідження вимогам, які ставлять перед товарами, виготовленими під належною торговою маркою законно. Для цього експерт досліджуе окремо оригінал товару та вилучений зразок за одними й тими ж показниками. Об'єктом дослідження може бути власне товар, його паковання, маркування та супровідна документація.

Базовим засобом товарознавчого дослідження для виявлення контрафрактності товару є ідентифрікація. Вона полягає у визначенні відповідності ряду характеристик (асортиментних, якісних, кількісних, тощо) і інформації про товар відповідно до вимог, які ставлять до оригінальної продукщії. Основними характеристиками товару, необхідними для його ідентифрікації $е$ : марка та модель виробу, комплектація, матеріал та фрізико-хімічний склад, країна та місце виготовлен- 
ня, дата придбання та період експлуатації, технічні характеристики, особливості офрормлення залежно від приналежності до групи товарів.

Наступним етапом дослідження $є$ вивчення товарної інформації, яку можуть містити: споживче чи транспортне паковання, етикетки, ярлики, штампи, тощо. Важливим аспектом $є$ визначення відповідності цієї інформації чинним стандартам. Неповнота, спотворення чи недостовірність інформації є основою для визнання товару контрадрактним. Найчастіше ці порушення виявляються в замовчуванні чи спотворенні інфрормації про: країну походження, адресу та найменування виробника, дати виготовлення, адреси та назви складу зберігання, категорії якості та групи товару та ін. [1, с. 575-580].

Отриману інформацію передають відповідним органам, які встановлюють контрафактність товару відповідно до інформащії, отриманої в процесі дослідження. Варто зазначити, що товарознавча є лише одним із видів експертизи, в процесі якої виявляють ознаки контрафактності товару. Зазвичай для цього проводять комплексне дослідження із застосуванням різних видів експертизи.

Висновки. Виявлення контрафрактних ознак товару під час товарознавчої експертизи полягає у його порівняльній оцінці відповідно до ряду показників. Експертиза вилученого зразка вимагає комплексного дослідження, у якому това- рознавча експертиза є лише одним з видів, але при цьому взаемодіе і з іншими видами аналізу об'єкта. Станом на сьогодні відомий ряд варіантів підробки оригінальних товарів відомих брендів і їх список збільшуеться. Це підвищуе актуальність дослідження товарів для виявлення ознак контрафрактності, як основи інформаційної доказової бази, необхідної для винесення максимально об'єктивного вироку судом.

Складність визначення поняття «контрадакція» зумовлена також і тим, що часто його плутають 3 поняттям «фальсифрікація», яке $є$ набагато ширшим. Варто зауважити, що такі випадки трапляються як на розмовному рівні, так і в професійній та науковій літературі.

Товарознавча експертиза контрафрактних товарів передбачає комплекс досліджень різних ознак товару від його паковання та визначення якісних і кількісних характеристик до перевірки оригінальності маркування торгових марок, нанесених на неї. Важливим аспектом є вивчення товарної інформації, яка знаходиться в супровідній та транспортній документащії. На транспортних пакуваннях, ярликах, тощо.

Матеріали цієї статті можуть стати основою для подальшого вивчення та вдосконалення методики, засобів і підходів товарознавчої експертизи контрафрактних товарів. Стаття також може бути матеріалом для вивчення у вищих навчальних закладах.

\section{Список літератури:}

1. Заніна Т. А. Комплексне дослідження фральсифікованої та контрафактної продукції: теоретичні та практичні аспекти. Теорія і практика судової експертизи і криміналістики. 2019. № 20. С. 573-583.

2. Еськова С. П., Коварда В. В. Контрафрактная и фальсифицированная продукция: понятия, сущность, отличительные особенности. Молодой ученый. 2016. № 20. С. 306-308.

3. Мазіна О. О. Контрафакція як дії, що порушують авторські права : авторедерат. 2014. 22 с.

4. Позова Д. Д. Про співвідношення понять «контрафрактні товари» та «фальсифіковані товари». Актуальні проблеми держави і права. 2012. Вип. 68. С. 256-262.

5. Селиванов А. А. Некоторые вопросы, связанные с контрафрактностью продукции. Теория и практика судебной экспертизы. 2011. № 4(24). С. 74-80.

\section{References:}

1. Zanina T. A. (2019) Kompleksne doslidzhennia falsyfikovanoi ta kontrafaktnoi produktsii: teoretychni ta praktychni aspekty [Comprehensive research of counterfeit and counterfeit products: theoretical and practical aspects]. Teoriia i praktyka sudovoi ekspertyzy i kryminalistyky, no. 20, pp. 573-583.

2. Es'kova S. P., Kovarda V. V. (2016) Kontrafaktnaja i fal'sificirovannaja produkcija: ponjatija, sushhnost', otlichitel'nye osobennosti [Counterfeit and falsified products: concepts, essence, distinctive features]. Molodoj uchenyj, no. 20, pp. 306-308.

3. Mazina O. O. (2014) Kontrafaktsiia yak dii, shcho porushuiut avtorski prava: avtoreferat [Counterfeiting as actions that violate copyright], $22 \mathrm{p}$.

4. Pozova D. D. (2012) Pro spivvidnoshennia poniat «kontrafaktni tovary» ta "falsyfikovani tovary» [On the correlation between the concepts of «counterfeit goods» and «counterfeit goods»]. Aktualni problemy derzhavy $i$ prava, no. 68 , pp. $256-262$.

5. Selivanov A. A. (2011) Nekotorye voprosy, svjazannye s kontrafaktnost'ju produkcii [Some issues related to counterfeit products]. Teorija i praktika sudebnoj jekspertizy, no. 4(24), pp. 74-80. 